\title{
Anti-infective properties of proton pump inhibitors: perspectives
}

\author{
Taciéli Fagundes da Rosa ${ }^{1}$ Vitória Segabinazzi Foletto ${ }^{1}$ Marissa Bolson Serafin ${ }^{1}$ - Angelita Bottega ${ }^{1}$. \\ Rosmari Hörner ${ }^{2}$ (I)
}

Received: 22 July 2021 / Revised: 9 August 2021 / Accepted: 10 August 2021 / Published online: 3 September 2021

(c) The Author(s), under exclusive licence to Springer Nature Switzerland AG 2021

\begin{abstract}
Infectious diseases are among the main causes of morbidity and mortality today. In facing this crisis, the development of new drug options and combat strategies is necessary. In this sense, drug repositioning or drug redirection has emerged for the faster identification of effective drugs. In this "Commentary," the anti-infective properties of the class of proton pump inhibitors (PPIs) are emphasized. Studies report activities against bacterial, fungal, parasitic, and viral agents. In addition, we have provided in a table a summary of the specific characteristics of PPIs and some of their anti-infective activities.
\end{abstract}

Keywords Anti-infective properties $\cdot$ Drug repurposing $\cdot$ Infectious diseases $\cdot$ Proton pump inhibitors

\section{Introduction}

Infectious diseases are among the main causes of morbidity and mortality today. This problem is compounded by the current crisis of resistance to antibacterial, antifungal, antiparasitic, and antiviral drugs, which has become a public health issue not only in terms of limited treatment options but also because of its economic burden. In facing this crisis, studies that analyze the causes of resistance and its expansion, together with the development of new drug options and combat strategies, are necessary (Nolte 2014; Gil-Gil et al. 2019; Nathan 2020).

\section{Commentary}

A promising alternative is drug repositioning. Repositioning, or also called redirection or repurposing, has been a trending topic in the literature and represents a new drug

Rosmari Hörner

rosmari.ufsm@gmail.com

1 Graduate Program in Pharmaceutical Sciences, Department of Clinical and Toxicological Analysis, Federal University of Santa Maria, Santa Maria, Rio Grande do Sul, Brazil

2 Bacteriology Laboratory, Department of Clinical and Toxicological Analysis, Health Sciences Center (CCS), Federal University of Santa Maria, UFSM, Building 26, Room 1201, Santa Maria, Rio Grande do Sul 97015-900, Brazil development strategy. This method consists of finding new uses for clinically approved drugs that already have a known chemical structure, toxicity, and safety profile. Thus, they can be redirected in the treatment of emerging diseases and pandemics, due to their speed of implementation, effectiveness, and lower costs when compared to the development of a new drug (Ashburn and Thor 2004; Serafin and Hörner 2018; Peyclit et al. 2019; Zhou et al. 2020).

Studies reporting the importance of drug repositioning for the treatment of infectious diseases are available, and among them we cite several classes, such as antidepressants (Bottega et al. 2020; da Rosa et al. 2020, 2021; Foletto et al. 2020, 2021; Machado et al. 2020; Serafin et al. 2020), antihypertensive (Hu et al. 2018), antihistamines (Bruer et al. 2019; El-Nakeeb et al. 2011), anti-inflammatory (Chan et al. 2017), alcohol-aversive agentes (Serafin et al. 2020), benzodiazepines (da Rosa et al. 2021), and statins (Rampelotto et al. 2018). In this commentary, the class of proton pump inhibitors (PPIs) is emphasized.

PPIs are known for their use in stomach acid-related disorders. Your representatives-dexlansoprazole, esomeprazole, lansoprazole, omeprazole, pantoprazole, rabeprazole, and tenatoprazole - are derived from the heterocyclic organic molecule benzimidazole and are first-line agents for the treatment of non-erosive reflux disease, peptic ulcer, Zollinger-Ellison syndrome, prevention of ulcers induced by non-steroidal anti-inflammatory drugs, eosinophilic esophagitis in pediatric patients, and eradication of 
Table 1 Summary of proton pump inhibitors and some of their anti-infective properties

\begin{tabular}{|c|c|c|c|c|c|c|c|}
\hline Drug & $\begin{array}{l}\text { Molecular } \\
\text { structure }\end{array}$ & $\begin{array}{l}\text { Chemical } \\
\text { formula }\end{array}$ & $\begin{array}{l}\text { Anti- } \\
\text { infective } \\
\text { activity (ies) }\end{array}$ & New indication & $\begin{array}{l}\text { Type } \\
\text { of study }\end{array}$ & Activity data & References \\
\hline Esomeprazole & & $\mathrm{C}_{17} \mathrm{H}_{19} \mathrm{~N}_{3} \mathrm{O}_{3} \mathrm{~S}$ & Antibacterial & Pseudomonas aeruginosa & In silico & $\begin{array}{l}\text { Virtually found as a } \\
\text { LasR inhibitor - system } \\
\text { that controls virulence } \\
\text { genes }\end{array}$ & Sadiq et al. \\
\hline \multirow[t]{8}{*}{ Lansoprazole } & & $\mathrm{C}_{16} \mathrm{H}_{14} \mathrm{~F}_{3} \mathrm{~N}_{3} \mathrm{O}_{2} \mathrm{~S}$ & Antibacterial & Mycobacterium tuberculosis & In vivo & $\begin{array}{l}\text { Dose }(\mu \mathrm{g} / \mathrm{mL}): 7.8411 \\
\text { and } 9.761 \\
\text { Mentioned that hen it is } \\
\text { administered } \\
\text { intraperitoneally, } \\
\text { significant amounts } \\
\text { penetrate the tissue, } \\
\text { being promising for } \\
\text { further anti-tuberculosis } \\
\text { tests }\end{array}$ & Mdanda et al.* \\
\hline & & & & Ureaplasma urealyticum & In vitro & $\mathrm{IC}_{50}(\mu \mathrm{M}): 12.5-25.0$ & Nagata et al. \\
\hline & & & Antifungal & Candida albicans & In vitro & IC $(\mu \mathrm{M}): \geq 200$ & Biswas et al. \\
\hline & & & & Candida spp. & In vitro & $\operatorname{MFC}(\mu \mathrm{g} / \mathrm{mL}): 128$ & Siavoshi et al. \\
\hline & & & Antiparasitic & $\begin{array}{l}\text { Trichomonas vaginalis } \\
\text { Giardia intestinalis } \\
\text { Entamoeba histolytica }\end{array}$ & In vitro & $\begin{array}{l}\mathrm{IC}_{50}(\mu \mathrm{M}): 0.1218 \\
\mathrm{IC}_{50}(\mu \mathrm{M}): 0.0731 \\
\mathrm{IC}_{50}(\mu \mathrm{M}): 0.3466\end{array}$ & Pérez-Villanueva et al. \\
\hline & & & & Plasmodium falciparum & In vitro & $\mathrm{IC}_{50}(\mu \mathrm{M}): 9.3$ & Riel et al. \\
\hline & & & Antiviral & Rhinovirus & In vitro & $\begin{array}{l}\text { Reduced supernatant } \\
\text { titers and RNA of } \\
\text { rhinovirus in tracheal } \\
\text { epitelial cells with } \\
\text { maximum effect with } \\
10 \mu \mathrm{M} \text { after } 48 \mathrm{~h}\end{array}$ & Sasaki et al. \\
\hline & & & & SARS-CoV-2 & In silico & $\begin{array}{l}\text { Reported } \\
\text { endolysosomal pH- } \\
\text { mediated effect } \\
\text { pKa data: } \\
\text { Strongest acidic: } 9.29 \\
\text { Strongest basic: } 4.77\end{array}$ & Homolak et al. \\
\hline \multirow[t]{4}{*}{ Omeprazole } & & $\mathrm{C}_{17} \mathrm{H}_{19} \mathrm{~N}_{3} \mathrm{O}_{3} \mathrm{~S}$ & Antibacterial & Ureaplasma urealyticum & In vitro & $\mathrm{IC}_{50}(\mu \mathrm{M}): 12500.00$ & Nagata et al. \\
\hline & & & & Enterococcus faecalis & In vitro & $\begin{array}{l}\text { Bacterial growth curves } \\
(\mathrm{mg} / \mathrm{L}): 300 \\
\text { Time zero: } 4 \log \\
\text { CFU/mL } \\
\text { After } 24 \mathrm{~h}: \text { less than } 1 \\
\log \mathrm{CFU} / \mathrm{mL}\end{array}$ & Jonkers et al. \\
\hline & & & & Staphylococcus aureus & & $\begin{array}{l}\text { Bacterial growth curves } \\
(\mathrm{mg} / \mathrm{L}): 300 \\
\text { Time zero: } 4 \log \\
\text { CFU/mL } \\
\text { After } 24 \mathrm{~h}: \text { less than } 1 \\
\log \mathrm{CFU} / \mathrm{mL}\end{array}$ & \\
\hline & & & & Staphylococcus aureus & In vitro & $\begin{array}{l}\text { Strain SA-1199 } \\
\text { MIC }(\mu \mathrm{g} / \mathrm{mL}): 1\end{array}$ & Vidaillac et al.* \\
\hline
\end{tabular}

Helicobacter pylori when in combination with antibacterials (Strand et al. 2017; Ward and Kearns 2013).

These drugs were clinically introduced over 25 years ago and have since proven to be invaluable, safe, and effective agents for the treatment of a variety of gastric acid-related disorders. Although adverse effects related to the use of PPIs have been reported, their clinical relevance is still unclear, as the evidence reported in these studies is based on retrospective observational studies. When compared to previous agents, this class demonstrates consistent patient tolerance, excellent safety, and generally superior acid-suppressing capacity. These are drugs widely used by the population, considering that omeprazole is among the 10 most prescribed in the USA (Perry et al. 2020; Strand et al. 2017).

PPIs have been continuously studied for presenting other activities, in addition to those already known and used commercially, and the most reported in the literature are the anti-infective ones. These properties are reported against different infectious agents: antibacterial activity, against Pseudomonas aeruginosa (Sadiq et al. 2020), Mycobacterium 
Table 1 (continued)

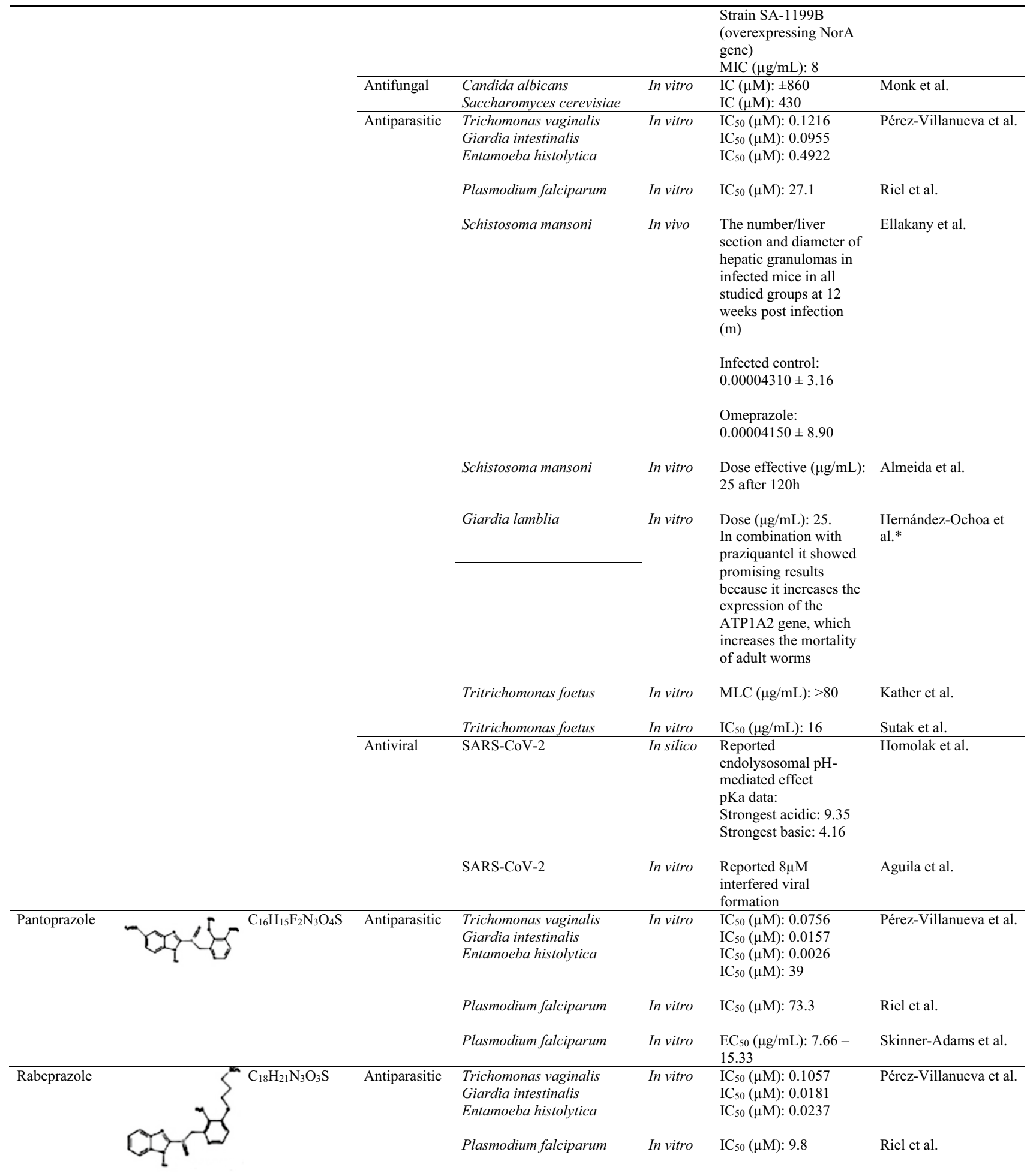

*Structure similar to the drug indicated

Captions of abbreviations and acronyms that appear in the table: $C F U$, colony forming unit; EC50, half maximum effective concentration; $I C$, inhibitory concentration; IC50, half of the inhibitory concentration; $M F C$, minimum fungicidal concentration; $M I C$, minimum inhibitory concentration; $M L C$, minimum lethal concentration

SOURCE: elaborated by the author, 2021 
tuberculosis (Mdanda et al. 2017), Ureaplasma urealyticum (Nagata et al. 1995), Enterococcus faecalis (Jonkers et al. 1996), and Staphylococcus aureus (Jonkers et al. 1996; Vidaillac et al. 2007); antifungal, against Candida albicans (Biswas et al. 2001; Monk et al. 1995), Candida spp. (Siavoshi et al. 2012), and Saccharomyces cerevisiae (Monk et al. 1995); antiparasitic, against Trichomonas vaginalis (Pérez-Villanueva et al. 2011), Giardia intestinalis (PérezVillanueva et al. 2011), Entamoeba histolytica (PérezVillanueva et al. 2011), Plasmodium falciparum (Riel et al. 2002; Skinner-Adams et al. 1997), Schistosoma mansoni (Almeida et al. 2015; Ellakany et al. 2019), Giardia lamblia (Hernández-Ochoa et al. 2017), and Tritrichomonas foetus (Sutak et al. 2004; Kather et al. 2007); antiviral, against SARS-CoV-2 (COVID-19) (Aguila and Cua 2020; Homolak and Kodvani 2020) and rhinovirus (Sasaki et al. 2005). In Table 1, we present a summary of the characteristics of PPIs and some of their anti-infective activities.

The activity of PPIs against COVID-19 is controversially reported. Some studies report that omeprazole would act positively against the virus, as previous studies had already reported that omeprazole was able to inhibit viral replication by interfering with the acidification of lysosomes. Drugs that affect the activity of vesicular acidification mechanisms neutralize endolysosomal compartments. A PPI can neutralize these compartments through inhibition of vacuolar-type $\mathrm{H}+$-ATPase (V-ATPase). Furthermore, it is still presented that the class of PPIs could help not only in the treatment, but also in the prophylaxis against the virus (Aguila and Cua 2020; Homolak and Kodvani 2020; Shen et al. 2017; Tastemur and Ataseven 2020; Vuille-dit-Bille et al. 2015).

On the other hand, other studies report that patients taking PPIs are at increased risk for serious clinical outcomes of COVID-19. It was found that individuals who take drugs in this class twice a day are more likely to report a positive test for SARS-CoV-2, when compared to those who use a lower dose up to once a day. The mechanism of this worrisome clinical outcome would occur because PPIs would alter one of the main functions of the gastric juice, which is to inactivate ingested microorganisms, thus inhibiting infectious agents from reaching the intestine (Almario, Chey and Spiegel 2020; Charpiat et al. 2020; Lee et al. 2021).

\section{Conclusions}

These considerations about the activities of PPIs against COVID-19 lead us to question what are the perspectives for the future use of PPIs as anti-infective agents?

Several drug classes that present significant adverse effects and control by medical prescription are used in studies with the objective of verifying the anti-infective activities. PPIs have a great advantage to be considered, since they are drugs that do not require a medical prescription to be marketed, have an excellent safety profile and ease of administration, and are among the most used drugs worldwide (Scarpignato et al. 2016). More studies are always welcome in clinical research to confirm the anti-infective potential of this class, but we can say that the therapeutic advantage will be great. Therapeutic activities are significantly reported in the literature, demonstrating the interest of researchers in this topic. Thus, the future perspectives for the use of anti-infective activities of PPIs are the best.

Author contribution T.F.R., V.S.F., M.B.S., A.B., and R.H.: the conception and design of the study, acquisition of data, analysis and interpretation of the data, drafting and critical revision of the manuscript, and final approval of the version to be submitted.

Funding This study was financed in part by the Coordenação de Aperfeiçoamento de Pessoal de Nível Superior-Brasil (CAPES)—Finance Code 001.

Data availability Not applicable.

Code availability Not applicable.

\section{Declarations}

Ethics approval Not applicable.

Consent to participate Not applicable.

Consent for publication Not applicable.

Conflict of interest The authors declare no competing interests.

\section{References}

Aguila EJT, Cua IHY (2020) Repurposed GI drugs in the treatment of COVID-19. Dig Dis Sci 65(8):2452-2453. https://doi.org/10. 1007/s10620-020-06430-z

Almario CV, Chey WD, Spiegel BMR (2020) Increased risk of COVID-19 among users of proton pump inhibitors. Am J Gastroenterol. 115(10):1707-1715. https://doi.org/10.14309/ajg.00000 00000000798

Almeida GT, Lage RC, Anderson L et al (2015) Synergy of omeprazole and praziquantel in vitro treatment against Schistosoma mansoni adult worms. PLoS Negl Trop Dis 9(9):e0004086. https://doi.org/ 10.1371/journal.pntd.0004086

Ashburn TT, Thor KB (2004) Drug repositioning: identifying and developing new uses for existing drugs. Nat Rev Drug Discov 3(8):673-683. https://doi.org/10.1038/nrd1468

Biswas SK, Yokoyama K, Kamei K et al (2001) Inhibition of hyphal growth of Candida albicans by activated lansoprazole, a novel benzimidazole proton pump inhibitor. Med Mycol 39:283-285. https://doi.org/10.1080/mmy.39.3.283.285

Bottega A, Serafin MB, da Rosa TF et al (2020) Antimicrobial and antineoplastic properties of sertraline. Am J Ther 27(6):e632-e635. https://doi.org/10.1097/MJT.0000000000001022 
Bruer GG, Hagedorn P, Kietzmann $\mathrm{M}$ et al (2019) Histamine $\mathrm{H}_{1}$ receptor antagonists enhance the efficacy of antibacterials against Escherichia coli. BMC Vet Res 15(1):55. https://doi.org/10.1186/ s12917-019-1797-9

Chan EWL, Yee ZY, Raja I et al (2017) Synergistic effect of non-steroidal anti-inflammatory drugs (NSAIDs) on antibacterial activity of cefuroxime and chloramphenicol against methicillin-resistant Staphylococcus aureus. J Glob Antimicrob Resist 10:70-74. https://doi.org/10.1016/j.jgar.2017.03.012

Charpiat B, Bleyzac N, Tod M (2020) Proton pump inhibitors are risk factors for viral infections: even for COVID-19? Clin Drug Investig 40(10):897-899. https://doi.org/10.1007/s40261-020-00963-x

da Rosa TF, Machado CS, Serafin MB et al (2020) Repositioning or redirection of antidepressant drugs in the treatment of bacterial and fungal infections. Am J Ther 27(5):e528-e532. https://doi. org/10.1097/MJT.0000000000001001

da Rosa TF, de S Machado C, Serafin MB et al. (2021) Repurposing of escitalopram oxalate and clonazepam in combination with ciprofloxacin and sulfamethoxazole/trimethoprim for treatment of multidrug-resistant microorganisms and evaluation of the cleavage capacity of plasmid DNA. Can J Microbiol. https://doi.org/ 10.1139/cjm-2020-0546

Ellakany AR, Elgendy DI, Alshenawy HA et al (2019) Assessment of the potential therapeutic effects of omeprazole in Schistosoma mansoni infected mice. Parasitol Res 118(12):3399-3408. https:// doi.org/10.1007/s00436-019-06465-w

El-Nakeeb MA, Abou-Shleib HM, Khalil AM et al (2011) In vitro antibacterial activity of some antihistaminics belonging to diferente groups against multi-drug resistant clinical isolates. Braz $\mathrm{J}$ Microbiol 42(3):980-991. https://doi.org/10.1590/S1517-83822 011000300018

Foletto VS, Serafin MB, Bottega A et al (2020) Repositioning of fluoxetine and paroxetine: study of potential antibacterial activity and its combination with ciprofloxacin. Med Chem Res 29:556-563. https://doi.org/10.1007/s11274-021-03016-3

Foletto VS, Da Rosa TF, Serafin MB et al (2021) Repositioning of antidepressant drugs and synergistic effect with ciprofloxacin against multidrug-resistant bacteria. World J Microbiol Biotechnol 37(3):53. https://doi.org/10.1007/s11274-021-03016-3

Gil-Gil T, Laborda P, Sanz-García F et al (2019) Antimicrobial resistance: a multifaceted problem with multipronged solutions. Microbiology Open 8(11):e945. https://doi.org/10.1002/mbo3.945

Hernández-Ochoa B, Navarrete-Vázquez G, Nava-Zuazo C et al (2017) Novel giardicidal compounds bearing proton pump inhibitor scaffold proceeding through triosephosphate isomerase inactivation. Sci Rep 7(1):7810. https://doi.org/10.1038/s41598-017-07612-y

Homolak J, Kodvanj I (2020) Widely available lysosome targeting agents should be considered as potential therapy for COVID-19. Int J Antimicrob Agents 56(2):106044. https://doi.org/10.1016/j. ijantimicag.2020.106044

$\mathrm{Hu}$ C, Li Y, Zhao Z et al (2018) In vitro synergistic effect of amlodipine and imipenem on the expression of the AdeABC efflux pump in multidrug-resistant Acinetobacter baumannii. PLoS ONE 13:e0198061. https://doi.org/10.1371/journal.pone.0198061

Jonkers D, Stobberingh E, Stockbrügger R (1996) Omeprazole inhibits growth of gram-positive and gram-negative bacteria including Helicobacter pylori in vitro. J Antimicrob Chemother 37(1):145150. https://doi.org/10.1093/jac/37.1.145

Kather EJ, Marks SL, Kass PH (2007) Determination of the in vitro susceptibility of feline Tritrichomonas foetus to 5 antimicrobial agents. J Vet Intern Med 21(5):966-970. https://doi.org/10.1892/ 0891-6640(2007)21[966:dotivs]2.0.co;2

Lee SW, Ha EK, Yeniova AÖ et al (2021) Severe clinical outcomes of COVID-19 associated with proton pump inhibitors: a nationwide cohort study with propensity score matching. Gut 70(1):76-84. https://doi.org/10.1136/gutjnl-2020-322248

Machado CS, da Rosa TF, Serafin MB et al (2020) In vitro evaluation of the antibacterial activity of amitriptyline and its synergistic effect with ciprofloxacin, trimethoprim-sulfamethoxazole and colistin as an alternative for drug repositioning. Med Chem Res 29:166-177. https://doi.org/10.1007/s00044-019-02470-x

Mdanda S, Baijnath S, Shobo A et al. (2017) Lansoprazole-sulfide, pharmacokinetics of this promising anti-tuberculous agent. Biomed Chromatogr. 31(12). https://doi.org/10.1002/bmc.4035

Monk BC, Mason AB, Abramochkin G et al. (1995) The yeast plasma membrane proton pumping ATPase is a viable antifungal target. I. Effects of the cysteine-modifying reagent omeprazole. Biochim Biophys Acta. 1239(1):81-90. https://doi.org/10.1016/00052736(95)00133-n

Nagata K, Takagi E, Satoh H et al. (1995) Growth inhibition of Ureaplasma urealyticum by the proton pump inhibitor lansoprazole: direct attribution to inhibition by lansoprazole of urease activity and urea-induced ATP synthesis in U. urealyticum. Antimicrob Agents Chemother. 39(10):2187-92. https://doi.org/10.1128/ AAC. 39.10 .2187

Nathan C (2020) Resisting antimicrobial resistance. Nat Rev Microbiol 18(5):259-260. https://doi.org/10.1038/s41579-020-0348-5

Nolte O (2014) Antimicrobial resistance in the 21st century: a multifaceted challenge. Protein Pept Lett 21(4):330-335. https://doi. org/10.2174/09298665113206660106

Pérez-Villanueva J, Romo-Mancillas A, Hernández-Campos A et al (2011) Antiprotozoal activity of proton-pump inhibitors. Bioorg Med Chem Lett 21(24):7351-7354. https://doi.org/10.1016/j. bmcl.2011.10.028

Perry IE, Sonu I, Scarpignato C et al (2020) Potential proton pump inhibitor-related adverse effects. Ann N Y Acad Sci 1481(1):4358. https://doi.org/10.1111/nyas.14428

Peyclit L, Baron SA, Rolain JM (2019) Drug repurposing to fight colistin and carbapenem-resistant bacteria. Front Cell Infect Microbiol 11(9):193. https://doi.org/10.3389/fcimb.2019.00193

Rampelotto RF, Lorenzoni VV, Silva DC et al (2018) Synergistic antibacterial effect of statins with the complex \{[1-(4-bromophenyl)3-phenyltriazene $\mathrm{N}_{3}$-oxide- $\kappa^{2} \mathrm{~N}^{1}, \mathrm{O}^{4}$ ] (dimethylbenzylamine- $\kappa$ ${ }^{2} \mathrm{C}^{1}, \mathrm{~N}^{4}$ )palladium(II) \}. Braz J Pharm Sci 54(02):e17369. https:// doi.org/10.1590/s2175-97902018000217369

Riel MA, Kyle DE, Bhattacharjee AK et al (2002) Efficacy of proton pump inhibitor drugs against Plasmodium falciparum in vitro and their probable pharmacophores. Antimicrob Agents Chemother 46(8):2627-2632. https://doi.org/10.1128/AAC.46.8.2627-2632. 2002

Sadiq S, Rana NF, Zahid MA et al (2020) Virtual screening of FDAapproved drugs against LasR of Pseudomonas aeruginosa for antibiofilm potential. Molecules 25(16):3723. https://doi.org/10. 3390/molecules 25163723

Sasaki T, Yamaya M, Yasuda $\mathrm{H}$ et al (2005) The proton pump inhibitor lansoprazole inhibits rhinovirus infection in cultured human tracheal epithelial cells. Eur J Pharmacol 509(2-3):201-210. https:// doi.org/10.1016/j.ejphar.2004.12.042

Scarpignato C, Gatta L, Zullo A et al (2016) Effective and safe proton pump inhibitor therapy in acid-related diseases - a position paper addressing benefits and potential harms of acid suppression. BMC Med 14:179. https://doi.org/10.1186/s12916-016-0718-z

Serafin MB, Hörner R (2018) Drug repositioning, a new alternative in infectious diseases. Braz J Infect Dis 22(3):252-256. https://doi. org/10.1016/j.bjid.2018.05.007

Serafin MB, Bottega A, Foletto VS et al (2020) Synergistic effect of sertraline and disulfiram against multidrug resistant bacteria as a new alternative to drug repositioning. Braz J Pharm Sci 56:e18089. https://doi.org/10.1590/s2175-97902019000418089 
Shen LW, Mao HJ, Wu YL et al (2017) TMPRSS2: a potential target for treatment of influenza virus and coronavirus infections. Biochimie 142:1-10. https://doi.org/10.1016/j.biochi.2017.07.016

Skinner-Adams TS, Davis TM, Manning LS et al (1997) The efficacy of benzimidazole drugs against Plasmodium falciparum in vitro. Trans R Soc Trop Med Hyg 91(5):580-584. https://doi.org/10. 1016/s0035-9203(97)90035-3

Siavoshi F, Tavakolian A, Foroumadi A et al (2012) Comparison of the effect of non-antifungal and antifungal agents on Candida isolates from the gastrointestinal tract. Arch Iran Med 15(1):27-31

Strand DS, Kim D, Peura DA (2017) 25 years of proton pump inhibitors: a comprehensive review. Gut Liver 11(1):27-37. https://doi. org/10.5009/gnl15502

Sutak R, Tachezy J, Kulda J et al (2004) Pyruvate decarboxylase, the target for omeprazole in metronidazole-resistant and ironrestricted Tritrichomonas foetus. Antimicrob Agents Chemother 48(6):2185-2189. https://doi.org/10.1128/AAC.48.6.2185-2189. 2004

Taştemur Ş, Ataseven H (2020) Is it possible to use Proton Pump Inhibitors in COVID-19 treatment and prophylaxis? Med Hypotheses 143:110018. https://doi.org/10.1016/j.mehy.2020.110018
Vidaillac C, Guillon J, Arpin C et al (2007) Synthesis of omeprazole analogues and evaluation of these as potential inhibitors of the multidrug efflux pump NorA of Staphylococcus aureus. Antimicrob Agents Chemother 51(3):831-838. https://doi.org/10.1128/ AAC.01306-05

Vuille-dit-Bille RN, Camargo SM, Emmenegger L et al (2015) Human intestine luminal ACE2 and amino acid transporter expression increased by ACE-inhibitors. Amino Acids 47:693-705. https:// doi.org/10.1007/s00726-014-1889-6

Zhou Y, Wang F, Tang J et al (2020) Artificial intelligence in COVID19 drug repurposing. Lancet Digit Health 2(12):e667-e676. https://doi.org/10.1016/S2589-7500(20)30192-8

Ward RM, Kearns GL (2013) Proton pump inhibitors in pediatrics: mechanism of action, pharmacokinetics, pharmacogenetics, and pharmacodynamics. Paediatr Drugs 15(2):119-131. https://doi. org/10.1007/s40272-013-0012-x

Publisher's note Springer Nature remains neutral with regard to jurisdictional claims in published maps and institutional affiliations. 